\section{FIAT JUSTISIA: JURNAL ILMU HUKUM}

Volume 12 Number 2, April-June 2018

P-ISSN: 1978-5186 | E-ISSN: 2477-6238

This work is available at: DOAJ

\title{
The Alternative Model Settlement of Credit Problems in Banking Agencies
}

\section{Lukmanul Hakim}

University of Bandar Lampung, Indonesia,email: Lukman517422@gmail.com

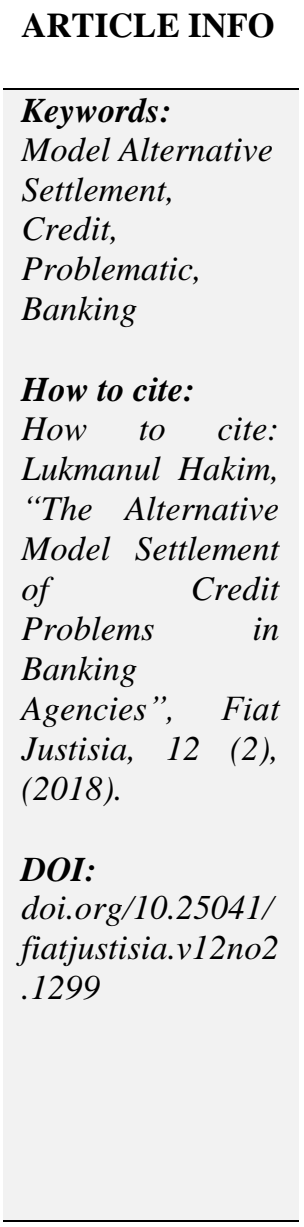

\begin{abstract}
Currently, the bank had a very important and very strategic role in various fields, as mandated by Law No. 7 on 1992 as amended and added into Law No. 10 on 1998 concerning banking where the bank has the main function of collecting and channeling the funds back to the community. Currently, the community cannot be separated from the banking world because it is no longer a public secret that banking services are very helpful towards the economic activities, especially entrepreneurs who want to expand their business. The research method used to answer the problems in this research is to use the normative legal research approach which is also called theoretical legal research or dogmatic legal research because it does not study the implementation of legal imperative. Data processing is done by several stages, namely data selection, data classification, and data systematics. Furthermore, the data is processed and analyzed qualitatively. The results of research and discussion show that legal certainty made by the government as an effort to protect the banks and debtors while the efforts that can be taken in settlement of troubled banks can be made by reconditioning, restructuring, and rescheduling. Besides the existence of $3 R$ as one of the problems solving loan models, there are also models of problem-solving loans such as selling collateral underhand or takeover.
\end{abstract}

Copyright () 2018 Fiat Justisia. All rights reserved. 


\section{A. Introduction}

The banking institution is one of the most important financial institutions and has a big role in the economic life of the community. The Bank is a financial institution that houses private individuals, private entities, state-owned enterprises, and even government institutions of their funds. Through credit activities and various services provided, banks that serve financing needs as well as launch a payment system mechanism for all sectors of the economy. ${ }^{1}$

Banking is one of the institutions that have a very important strategic role in various fields, especially in community activities in the field of finance, as well as economic activities to meet the personal needs of the community. Currently, the community cannot be separated from the banking world because it is no longer a secret that the banking services are very helpful towards the economic activities, especially the entrepreneurs who want to develop their business. ${ }^{2}$ The main function of banking according to Article 3 of the Banking Act is as a Financial Intermediary that is to collect funds and channel funds to the public. Where in the purpose of channeling funds to the community in the form of credit to improve the national development and to provide the welfare of society in the business sector as a driver of the national economy.

Implementation of community welfare through a banking institution can be realized through the form of development of the economic sector as wide as possible. According to Sunaryati Hartono, legal development is done continuously and is a process that never finishes, because there are always changes that encourage the growth rate not only for the community but also for financial and non-financial institutions. ${ }^{3}$ Also, banks are also agents of trust of the community considering the existence of one of the principles of bank management namely the principle of trust (fiduciary principle) so that banks in providing loans in the form of credit always guided by prudential banking principle. Regarding the prudential banking arrangements contained in Article 29 paragraphs 2 and 3 of the Banking Act, ${ }^{4}$ which is a variety of provisions necessary to ensure the survival and management of banks healthily to maintain public trust and perform its functions as an intermediary institution and service payment system for the economy. ${ }^{5}$

\footnotetext{
1 Tarsisius Murwaji dan Achmad Hagy Roby, "Edukasi dan Penyehatan Koperasi Melalui Linkage Program Perbankan”, Padjadjaran Jurnal Ilmu Hukum, 4 (3), (2017), pp. 464

${ }^{2}$ Lukmanul Hakim, "Analisis Alternatif Penyelesaian Sengketa Antara Pihak Nasabah Dengan Industri Jasa Keuangan Pada Era Otoritas Jasa Keuangan", Jurnal Keadilan Progresif, 6 (2), (2015), p. 162

${ }^{3}$ CFG. Sunaryati Hartono, Hukum Ekonomi Pembangunan Indonesia, Bandung: Bina Cipta, (1988), p. 8

${ }^{4}$ Article 29 Law of Banking

${ }^{5}$ Lukmanul Hakim, Loc.Cit., p. 162
} 
The implementation of the precautionary principle is intended to avoid bank business risk, as one of the functions of the bank is to distribute credit in one of its business activities so that the risk of this business should be avoided. One of the business risks that exist in the banking institution, among others is in credit risk or default risk, is a risk due to failure or inability of customers to return the loan amount received from the bank and its interest by the scheduled period. ${ }^{6}$

From the description of the above background, several problems are consisting of; 1) What is the legal certainty in settlement of non-performing loans at banking institutions? And; 2) What are the alternative solutions for non-performing loans at banking institutions? The type of research conducted in this study is normative legal research that is also called as theoretical legal research or dogmatic legal research because it does not assess the implementation of legal imperative. Understanding of normative law research conducted by examining library materials or secondary data only. ${ }^{7}$ The type of research used in this study is descriptive. According to Abdulkadir Muhammad, descriptive legal research exposes and aims to obtain an overview of existing facts or a full description of the latest legal conditions prevailing in certain places that occur in society. ${ }^{8}$

\section{B. Discussion}

\section{Legal Certainty in Settlement of Problematic Credit at Banking Institution}

Indonesia is a State which is based on the applicable law and is not based on power, as affirmed by the 1945 Constitution which means that Indonesia is a State of Law (Rechtstaat) in which the actions of the government and other institutions shall be in accordance with the applicable law in Indonesia, where the law in its exercise can be imposed and aims to obtain justice and legal certainty. ${ }^{9}$

Legal certainty is necessary to ensure peace and order in society, institutions, and government that is implemented in everyday community activities. As affirmed in Article 1 paragraph 3 of the 1945 Constitution (Fourth Amendment) that Indonesia is the State of Law. ${ }^{10}$ According to the

\footnotetext{
${ }^{6}$ Dahlan Siamat, Manajemen Lembaga Keuangan, Edisi Kedua, Jakarta: Ekonomi Universitas Indonesia, (1999), p. 83

${ }^{7}$ Soerjono soekanto dan sri mamuji, Penelitian Hukum Normatif Suatu Tinjauan Singkat, Jakarta: Raja Grafindo Persada, (2010), p.13

${ }^{8}$ Abdulkadir Muhammad, Hukum dan Penelitian Hukum, Bandung: Citra Aditya Bakti, (2004), pp 50

${ }^{9}$ Zulfi Diane Zaini, Independensi Bank Indonesia dan Penyelesaian Bank Bermasalah, Bandung: Keni Media, (2012), p. 41

${ }^{10}$ Article 1 point 3 Fourth Amandement of the Constitution of Indonesia 1945
} 
Big Indonesian Dictionary, the meaning of the Law is the rule, by the rules or legislation, the provisions or even the policies made by the rulers of great importance to be noticed by the public. ${ }^{11}$

Provisions and rules made by the state may be a limitation for the public or institution in imposing any action on the individual and the implementation of the rules that give rise to legal certainty. Legal Certainty contains two definitions, namely :

a. The existence of rules that are general to make the individual know what deeds that may or should not be done;

b. The existence of legal security for individuals from the abuse of the government because with the existence of a rule that is general and applicable to all the society individual can know what may be charged or done by the state to the individual. ${ }^{12}$

Issued between legal certainty between banking institutions and the community strongly has a very close relationship to the development and advancement of the economic sector where the banking institutions today as one of the business sectors in the financial system in Indonesia that can support the economic development in particular. The policies contained in today's banking institutions are comprehensive, transparent accountable, and contain legal certainty.

Problems in financial institutions, especially banks should be prevented and handled to avoid disturbance and distrust of the public for banking institutions, especially in bank lending should be more careful because remembering the bank must maintain the level of health in order to build a good and stable financial system it needs a device the legal rule (legal framework) that can be the basis of the foundation for the implementation of the main function of the bank as a whole.

In connection with the description above, it can be explained that the legal device has a role as a foundation of banking system legal instruments in the implementation of activities related to the development of banking law and national economic law as a whole in order to provide legal certainty for users of banking services, especially people in Indonesia. One form of legal certainty in a banking institution is contained in Bank Indonesia Regulation no. 7/2 / PBI / 2005 as amended by Bank Indonesia Regulation no. 8/2 / PBI / 2006 concerning Asset Quality Rating for Commercial Banks which regulates the classification of credit based on loan collectibility that describes credit quality. According to Article 12 Paragraph (3) of Bank Indonesia Regulation No. 7/2 / PBI / 2005 Asset Quality Rating for Commercial Banks may be divided into five collectibles: Current (C),

\footnotetext{
${ }^{11}$ Departemen Pendidikan dan Kebudayaan, Kamus Besar Bahasa Indonesia, Jakarta, (2010), p. 238.

12 Peter Mahmud Marzuki, Pengantar Ilmu Hukum, Jakarta: Kencana, p. 158
} 
Special Attention (SA), Substandard (S), Doubtful (D), and Loss (L). Which is described as follows :

a. Current Credit is if the debtor fulfills the following criteria:

1) Payment of principal installment and interest on time according to schedule.

2) Have an active account mutation.

3) Cash collateral secures part of the credit.

b. Credit in Special Attention that is if it meets the following criteria:

1) There are arrears in principal and unpaid interest over 90 days.

2) Account movements that are not very active and tend to be low

3) Supported by new loans.

c. Substandard Credit that is when it meets the following criteria:

1) There are unpaid interest arrears and unpaid interest over 90 days.

2) Account movements that are not very active and tend to be low.

3) There are indications of financial problems faced by the debtor.

4) Weak loan documentation.

d. Doubtful Credit (D) is to meet the following criteria:

1) There are arrears in installments or interest beyond 180 Days.

2) The occurrence of a default by the debtor.

3) Interest Capitalization occurred.

4) Weak legal documentation for both credit agreements and increased guarantees.

e. Bad Debt (M) if it meets the following criteria:

1) There are arrears of principal or interest beyond 270 Days.

2) b. Regarding law or market conditions, the guarantee cannot be cashed at fair value.

In the provision of Credit of course the bank must also apply some basic principles such as the application of the principles of Principle 5C, 5P, and $3 \mathrm{R}$ in the provision of credit that is used to minimize the risk of nonperforming loans or even result in bad debts and provide legal certainty for the banks and debtors in the future day. ${ }^{13}$ In the application of the $5 \mathrm{C}$ principle as follows :

\section{a. Character}

In the character assessment, the character debtor is the most important thing considering the obligation to be executed by the debtor to pay off the existing credit. Characters in crediting may include the character, morals, nature, willingness and obligations of the debtor. Also, the fulfillment of information about the debtor can be obtained by the bank through credit history that can be viewed through the exchange of information through

${ }^{13}$ Hermansyah, Hukum Perbankan Nasional Indonesia, Jakarta: Kencana, (2009), p. 63 
consumer information service system managed by the Financial Services Authority.

\section{b. Capacity}

The definition of capacity is usually intended to determine the ability of prospective borrowers in fulfilling their obligations during the period specified by the bank. Measurement of the ability of a debtor can be seen from the material approach of the financial assessment of the debtor candidate for example from the financial statements for employers and income slips for employees so that it could be known the level of solvency, liquidity, and rentability of the debtor. Besides, which can be used as an indicator of this capacity among others is business experience/work, debtor education, business competition with another competitor. So the better the ability of a person than the better the possibility of credit quality.

c. Capital

Capital is something that needs to be analyzed in depth by the banking because the distribution of capital placed by employers or credit applicants to use credit. So, a debtor is considered to have sufficient capital to get credit. So, the greater the capital or down payment paid by the debtor, the more convincing the bank that the credit is likely to be given.

\section{d. Collateral}

Collateral is a guarantee/collateral provided by prospective borrowers to the bank. The Bank will not provide credits that exceed the value of the guarantee, except for certain credits that do not require such collateral. The guarantee may also be a means of protection or protection or a safeguard against the risk of default by the debtor.

\section{e. Condition of Economy}

It is an analysis of economic conditions where the bank needs to pay attention between the business sector of the debtor which is related to the current economic condition where it will affect the level of payment from the debtor so that the risk to the credit that will be a problem can be minimized before the credit is given.

The bank needs to pay attention to the business sector of the debtor is related to the current economic condition where it will affect the level of payment from the debtor so that the risk to the credit that will be a problem can be minimized before the credit is given as for the meaning of $5 \mathrm{P}$ described as follows: ${ }^{14}$

a. Party

The Bank evaluates several classes consisting of character, capacity, the capital where the three principles of this bank can decide between giving credit to prospective borrowers.

\footnotetext{
${ }^{14}$ Ismail, Manajemen Perbankan, Kencana, Jakarta, (2010), p. 114
} 


\section{b. Purpose}

More focused on the purpose of the use of credit to be filed by the debtor. Where the bank will see and analyze the purpose of credit proposed by the prospective debtor.

\section{c. Payment}

The Bank analyzes before deciding whether the credit applicant is viable or not through the calculation of income or income estimation through the debtor's financial statement so that it can be estimated about the estimated time of credit repayment by the debtor.

d. Profitability

Profitability, not limited to the benefits of prospective borrowers. Also, banks also need to take into account the amount of income that will be received by banks through credit in the form of interest, commissions, feebased income and others.

e. Protection

In the most important lending is the protection of the bank or the debtor through a guarantee that provides security to each party before the occurrence of problems in credit.

Aside from applying the last $5 \mathrm{C}$ and $5 \mathrm{P}$ principles in the basic principle of further credit is $3 \mathrm{R}$ which is useful in making decisions for lending include the following :

a. Return

b. Repayment

c. Risk Bearing Ability

The concept of $5 \mathrm{P}$ and $3 \mathrm{R}$ is the development of the previous concept called 5C, but currently, the concept of 5C in practice becomes more popular in Banking because it includes both 5P and 3R concepts. In the concept of granting credit using the $5 \mathrm{C}, 5 \mathrm{P}$, and $3 \mathrm{R}$ principles, it is expected to minimize or prevent the occurrence of non-performing loans so that banks do not need to make bank reserves for loans that are less qualified and banks can continue to improve bank soundness.

\section{Alternative Settlement of Troubled Loans at Banking Institutions}

Every bank must experience and face problem loans, banks that do not have problem loans even strange even except the newly established bank. Nonperforming loans are a risk faced by banking institutions. ${ }^{15}$ Nonperforming loans represent loans that have been distributed by the bank, but the debtor cannot fulfill its obligations resulting in a default of the

15 Muhamad Djumhana, Hukum Perbankan di Indonesia, Bandung: Citra Aditya Bakti, (2000), p. 427 
agreements made by the bank and the debtor. The assessment of the classification of credit, whether it is current or non-performing loans can be done both quantitatively and qualitatively. The assessment is quantitatively seen from the ability of debtors in making payments installment credit. The qualitative credit rating can be seen from the business prospects and financial condition of the debtor. ${ }^{16}$ On performing loans will result in a bank loss, i.e., non-receipt of interest income means the bank loses the opportunity to earn interest, which results in a decrease in total income. ${ }^{17}$ Also, nonperforming loans also have an impact on banks, namely:

a. Bank earnings/losses decreased, which resulted from a decrease in interest income on loans.

b. Bad Debt Ratio becomes lower, earning asset ratio becomes lower.

c. The cost of provision for credit elimination increases, because this fee serves for the elimination of credit that will affect the decline in bank profits.

d. ROA and ROE decline decreased earnings will have an impact on the decrease in ROA because returns fall, then ROA and ROE will decrease. ${ }^{18}$

Before the bank decides to approve or reject the loan application from the prospective debtor to avoid any problems with existing and distributed loans. However, although banks have been carefully analyzed, the risk of problem loans is also likely to continue. ${ }^{19}$

Regarding the legal risks that occur in non-performing loans must be settled early and as soon as possible and the bank may not make exceptions in settlement of non-performing loans. Regarding the settlement of nonperforming loans can be done based on Bank Indonesia Circular Letter no. 26/4 / BPPP dated May 29, 1993, which principally regulates the rescue of problem loans before being settled through the judiciary. The settlement of problem loans can be done in a way:

a. Rescheduling

It is a legal effort by a bank to deal with problem loans by making rescheduling and changing the period against some terms of the credit agreement.

b. Reconditioning

Is an attempt to make changes in the form of interest rate reduction, or partial redemption of an interest in arrears and delays in interest payments.

c. Restructuring

\footnotetext{
${ }^{16}$ Ismail, Op.Cit., p. 123

${ }^{17}$ Ibid., p. 123

${ }^{18}$ Ibid., p. 125

${ }^{19}$ Lukmanul Hakim, "Analisis Penerapan Prinsip Kehati-hatian Dalam Pemberian Kredit Kepada Nasabah”, Thesis, Bandar Lampung, (2013)
} 
Bank efforts in the form of changes in the structure of financing such as providing additional credit by banks to support the smooth operation of the company.

d. Combination

Bank efforts made by combining rescheduling and restructuring, rescheduling and reconditioning, restructuring and reconditioning or rescheduling, restructuring and reconditioning are combined to make the maximum effort.

e. Execution

Parate execution is the last alternative that can be taken by banking institutions to rescue problem loans. The execution can be done by selling the guarantee and then the proceeds of the sale to cover the obligation to be paid, while the remaining sales must be returned to the debtor. The execution of collateral items in nonperforming loans can be done if the loan disbursement is completely unenforceable. Then the bank will withdraw the guarantee object and sell through the auction submitted to the State Wealth Service Office and Auction (KPKNL). The Bank cooperates with the State Wealth Service Office and Auction (KPKNL) in conducting the auction of guarantee items. The provisions are regulated in Article $12 \mathrm{~A}$ paragraph 1 of Act Number 7 of 1992 concerning Banking as amended by Act Number 10 of 1998 stating "Commercial Bank may purchase part or all of collateral either through the auctions or outside the auctions based on the delivery voluntarily by the owner of the collateral or by the power to sell outside the auction of the collateral owner in the event that the Debtor Customer does not comply with its obligations to the bank, provided that the collateral is purchased shall be disbursed as soon as possible." 20

The settlement of non-litigation non-performing loans is a win-win solution. Steps to achieve problem-solving loans in a mutually beneficial manner can thus be achieved through means, consultation, negotiation, mediation, conciliation. Non-litigation lane from the litigation lane, the consideration relates to the problem:
a. Cost
b. Time
c. Results achieved
d. Debt good faith
e. Ability to pay

This step can be done if the parties are basing on good faith. Furthermore, if the above completion efforts have not provided results, especially in settlement of credit problems then it can be taken further efforts through the judiciary if in this case, the debtor does not meet its obligations

${ }^{20}$ Article 12 point 1 Banking Law 
then each debtor can file a lawsuit to obtain a court decision. The court can solve and handle the problem loans general courts through civil suit, commercial court through bankruptcy lawsuit. Also, other non-performing loans can be settled by arbitration as mandated by Law No. 30/1999 on Arbitration which can be taken in solving problems in banking institutions where one of them is non-performing loans which can be poured in the credit agreement. Furthermore, the settlement of nonperforming loans can also be seen in Appendix POJK Number 42. In the event that the total amount of Credit or Financing whose collectibility is classified as Doubtful and Loss has reached $7.5 \%$ (seven point five percent) of the total Creditor Financing amount or any other criteria stipulated by the Financial Services Authority that classifies the Bank as a Bank facing Credit or Non-performing Financing, the Board of Directors, shall establish and take steps, at least as follows :

a. Report of Credit or Non-performing Financing to the Financial Services Authority The Bank must promptly submit a written report to the Financial Services Authority if the amount of Credit or Financing whose collectibility is classified as Doubtful and Loss have reached such criteria.

b. Establishment of a Working Unit or Working Group or Working Team for Settlement of Credit or Non-Performing Financing The Bank shall establish a work unit or working group or working team or in the PPKPB the term "Special Task Force" (STK) is responsible for resolving Credit or Non-performing Financing. Officials designated in STK are established by the Board of Directors and reported to the Financial Services Authority. The Bank may assign its name to the STK.

c. Preparation of Credit Settlement Program or Non-Performing Financing The Bank shall develop a settlement program for Credit or Nonperforming Financing and promptly submit the program to the Financial Services Authority with due regard to the matters as follows:

1) STK prepares a Credit or Problem financing settlement program to be submitted to the directors for approval. The program at least includes:

i. Procedures for settlement of Credit or Financing problems with due regard to the terms of the settlement of Credit or Nonperforming Financing applicable to the Bank;

ii. Estimated timeframe;

iii. Estimated settlement of Credit or Financing problem; and

iv. To the extent possible prioritize the settlement of Credit or Problem Financing to parties related to the Bank and major debtors.

2) The loan or problem financing settlement program must be by CDE. If there is a way of settling Credit or Non-performing Financing 
which is judged to be more effective than that contained in CDE, the Board of Directors may execute such method after obtaining approval from the Board of Commissioners.

3) Implementation of a Completed Credit or Financing Settlement Program A problem-solving program for Credit or Non-performing Financing shall be carried out promptly, at least including:

i. The implementation of the settlement of Credit or NonPerforming Financing shall be done in full by STK based on a program approved by the Board of Directors. If STKs require assistance or support from other officials or work units, the board of directors must ensure that such assistance or support can be obtained immediately;

ii. STK shall periodically evaluate the progress of the settlement of Credit or Non-performing Financing and report the evaluation result to the Board of Directors with a copy to the board of commissioners with the required explanation; and

iii. The results of the implementation of the Loan settlement or Non-performing financing program are reported by the Board of Directors to the Financial Services Authority. To ensure that the troubled Credit or Financing settlement steps under the program have been carried out properly and effectively, the Financial Services Authority will at any time engage in direct communication with STK

4) The evaluation of the Effectiveness of a Loan Settlement Program or Non-Performing Financing At least once every 6 (six) months after a credit or non-performing financing settlement program has been implemented, or other grace period stipulated by the Financial Services Authority, the Bank shall evaluate the effectiveness of the Loan or Problem financing settlement program,

i. In the event that the number of Loans or Non-performing Financing is well below the predicted (Targets) of the planned Loan or Financing Financing planned, whereas the implementation of the problematic Credit or NPL settlement has been implemented optimally, the STK proposes to the Board of Directors the changes or improvements to the settlement program of Credit or Necessary Financing.

ii. The results of the evaluation on the effectiveness of the settlement program of Credit or Necessary Financing as well as changes or improvements to the program must be immediately reported to the Financial Services Authority. ${ }^{21}$

${ }^{21}$ Lampiran POJK Nomor 42 
Based on the above description, the authors can conclude that the application of the principles $5 \mathrm{C}, 5 \mathrm{P}$ and $3 \mathrm{R}$ can make the indicator of problem loans can be minimized early on in addition to the model settlement other disputes may also use an out-of-court dispute settlement either selling underwritten warranties or expropriation or dispute settlement through arbitration allowing banks and borrowers to have a win-win solution.

\section{Conclusion}

\section{Conclusion}

Based on the results of research and discussion, the conclusions of this research are as follows:

a. The role of government and state provides a legal certainty especially in the application of banking institutions provide protection for banks and debtors by applying the principle of $5 \mathrm{C}$ in the provision of credit to minimize the occurrence of problem loans at the beginning and when there is a problem loan, it can be settled disputes through the arbitration as mandated by Law No. 30 on 1999 on Arbitration

b. Also, the efforts that can be taken in the problem-solving loan model can, among others, use restructuring, rescheduling, reconditioning or a combination of the three. It can also be reached through the courts if necessary.

\section{Suggestion}

a. Banking institutions should be able to apply prudential principles in the provision of credit with the implementation of $5 \mathrm{C}$ is also considered quite an impact in lending, in particular, to minimize the occurrence of non-performing loans so that non-performing loans did not occur early;

b. The debtor is expected to provide information and information by the data and facts that exist in the field as an attempt to provide credit to the debtor does not affect the poor credit quality. So, it is expected in settlement of debtor; problem loans can also be more cooperative regarding delivery of data information itself. 
Book

\section{Bibliography}

Departemen Pendidikan dan Kebudayaan. (2010). Kamus Besar Bahasa Indonesia. Jakarta

Djumhana, Muhamad. (2000). Hukum Perbankan di Indonesia. Bandung:

Citra Aditya Bakti

Hartono, CFG. Sunaryati. (1988). Hukum Ekonomi Pembangunan Indonesia, Bandung: Bina Cipta

Hermansyah. (2009). Hukum Perbankan Nasional Indonesia. Jakarta: Kencana

Ismail. (2010). Manajemen Perbankan. Jakarta: Kencana

Marzuki, Peter Mahmud. (2002). Pengantar Ilmu Hukum. Jakarta: Kencana

Muhammad, Abdulkadir. (2004). Hukum dan Penelitian Hukum. Bandung: Citra Aditya Bakti

Siamat, Dahlan. (1999). Manajemen Lembaga Keuangan. Jakarta: Fakultas Ekonomi Universitas Indonesia

Soekanto, Soerjono dan Mamuji, Sri. (2010). Penelitian Hukum Normatif Suatu Tinjauan Singkat. Jakarta: Raja Grafindo Persada

Zaini, Zulfi Diane. (2012). Independensi Bank Indonesia dan Penyelesaian Bank Bermasalah. Bandung: Keni Media

Journals and Article

Lukmanul Hakim. "Analisis Alternatif Penyelesaian Sengketa Antara Pihak

Nasabah Dengan Industri Jasa Keuangan Pada Era Otoritas Jasa Keuangan”, Jurnal Keadilan Progresif, 6 (2), (2015).

Lukmanul Hakim. "Analisis Penerapan Prinsip Kehati-hatian Dalam

Pemberian Kredit Kepada Nasabah”, Tesis, Bandar Lampung, (2013)

Murwaji, Tarsisius. dan Roby, Achmad Hagy. "Edukasi dan Penyehatan

Koperasi Melalui Linkage Program Perbankan", Padjadjaran Jurnal Ilmu Hukum, 4 (3), (2017), https://doi.org/10.22304/pjih.v4n3.a2

\section{Legislations}

Republic of Indonesia Law No. 30 on 1999

Republic of Indonesia Law No. 7 on 1992

The Constitution of the Republic of Indonesia 1945

The Letter of Indonesian Bank No. 26/4/BPPP

The Rule of Indonesian Bank No. 7/2/PBI/2005

The Rule of OJK No. 42 /POJK.03/2017 